Illinois State University

ISU ReD: Research and eData

Theses and Dissertations

$3-17-2021$

\title{
Professional Sport And Community Outreach: A Content Analysis Of Csr Messages Shared By Professional Team Sport Organizations On Twitter
}

Kelly E. Murphy

Illinois State University, kellymurphy685@gmail.com

Follow this and additional works at: https://ir.library.illinoisstate.edu/etd

Part of the Communication Commons

\section{Recommended Citation}

Murphy, Kelly E., "Professional Sport And Community Outreach: A Content Analysis Of Csr Messages Shared By Professional Team Sport Organizations On Twitter" (2021). Theses and Dissertations. 1397. https://ir.library.illinoisstate.edu/etd/1397

This Thesis is brought to you for free and open access by ISU ReD: Research and eData. It has been accepted for inclusion in Theses and Dissertations by an authorized administrator of ISU ReD: Research and eData. For more information, please contact ISUReD@ilstu.edu. 


\section{PROFESSIONAL SPORT AND COMMUNITY OUTREACH: A CONTENT ANALYSIS OF CSR MESSAGES SHARED BY PROFESSIONAL TEAM SPORT ORGANIZATIONS ON TWITTER}

\section{KELLY E. MURPHY}

60 Pages

This study seeks to understand the corporate social responsibility (CSR) topics shared by professional team sport organizations on their websites and on Twitter as well as fan responses to those CSR messages. A quantitative content analysis of individual tweets from 16 teams across the NFL, NBA, MLB, and NHL posted from October 1-30, 2020 was conducted. Results indicate that CSR topic frequencies were significantly different both on webpages and on Twitter. Replies to CSR messages on Twitter were significantly different based on topic, and replies were largely neutral. There was no significant difference in reply valence to CSR tweets that were community-specific compared to tweets that were not community-specific. Practical implications, limitations, and directions for future research are discussed.

KEYWORDS: Corporate social responsibility (CSR), professional team sport organizations (PTSO), social media, fan identification, corporate reputation 
PROFESSIONAL SPORT AND COMMUNITY OUTREACH: A CONTENT ANALYSIS OF CSR MESSAGES SHARED BY PROFESSIONAL TEAM SPORT ORGANIZATIONS ON TWITTER

KELLY E. MURPHY

A Thesis Submitted in Partial Fulfillment of the Requirements for the Degree of

MASTER OF SCIENCE

School of Communication

ILLINOIS STATE UNIVERSITY

2021 
(C) 2021 Kelly E. Murphy 
PROFESSIONAL SPORT AND COMMUNITY OUTREACH: A CONTENT ANALYSIS OF CSR MESSAGES SHARED BY PROFESSIONAL TEAM SPORT ORGANIZATIONS ON TWITTER

KELLY E. MURPHY

COMMITTEE MEMBERS:

Rebecca Hayes, Co-Chair

John Hooker, Co-Chair

Joseph Blaney 


\section{ACKNOWLEDGMENTS}

First I would like to thank my committee for their help in all aspects of my thesis and for their support throughout this process. I never anticipated writing a thesis during a global pandemic, but your commitment to my thesis and academic growth is so appreciated. Dr. Hayes, thank you for sparking my interest in public relations and for your guidance in researching corporate social responsibility. Without you sharing your expertise with me I would not have found my passion for CSR and for understanding its impact on communities. Also, my thesis would not have existed without the support I received from Dr. Hooker. Dr. Hooker, your methodological expertise and your ability to help me understand and navigate the research process was invaluable, and I am very grateful. Finally, Dr. Blaney you have been an extremely supportive member of my committee, and I am so thankful for your commitment to my research.

Next, to my cohort whom I miss very much. Grad school has been an exciting and challenging process, and I have not seen most of you in over a year. I am endlessly grateful for Zoom coffee chats, park hangouts, and other innovative ways we have stayed connected during a sensationally stressful academic period.

Finally, to my family and friends, I am so grateful for you. I could not have completed this project without your encouragement, and I feel very lucky to have you all as my support system.

K. E. M. 


\section{CONTENTS}

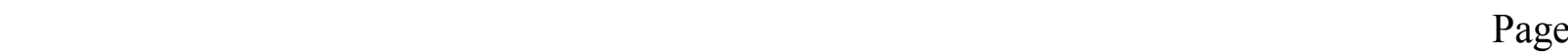

ACKNOWLEDGMENTS

CONTENTS

TABLES

CHAPTER I: INTRODUCTION 1

CHAPTER II: REVIEW OF LITERATURE

Corporate Social Responsibility 3

CSR and Professional Team Sport Organizations 4

Internal Motivations for CSR

$\begin{array}{ll}\text { Outcomes of CSR } & 7\end{array}$

$\begin{array}{lr}\text { Fan Identification } & 8\end{array}$

$\begin{array}{ll}\text { Brand Loyalty } & 10\end{array}$

$\begin{array}{ll}\text { Corporate Reputation } & 12\end{array}$

$\begin{array}{ll}\text { Sharing CSR Initiatives } & 14\end{array}$

$\begin{array}{ll}\text { How CSR Initiatives are Shared } & 15\end{array}$

$\begin{array}{ll}\text { What CSR Initiatives are Shared } & 17\end{array}$

$\begin{array}{ll}\text { Engagement } & 18\end{array}$

CHAPTER III: METHODS 24

$\begin{array}{ll}\text { Sample } & 24\end{array}$

$\begin{array}{ll}\text { Part } 1 & 25\end{array}$

$\begin{array}{ll}\text { Part } 2 & 27\end{array}$

CHAPTER IV: RESULTS $\quad 30$ 
CSR Topic

Engagement

Practical Implications

Limitations

Directions for Future Research

CHAPTER VI: CONCLUSION 


\section{TABLES}

Table

Page

1. Frequency of CSR Topic on PTSO Community Webpages

2. Frequency of CSR Topic on PTSO Twitter Accounts

3. Reply Valence to CSR Tweets

4. Reply Valence to CSR Topic on Twitter

5. Frequency of Community-Specific Tweets

6. Reply Valence to Community-Specific Tweets 


\section{CHAPTER I: INTRODUCTION}

This study seeks to examine the corporate social responsibility (CSR) messages that professional team sport organizations (PTSOs) share on Twitter, analyzing both the frequency of certain topics of messages, and then the resultant engagement on those messages. As social media continues to be a necessary outlet for brands and organizations to disseminate information the subsequent social noise resulting from too many brand messages increases the importance of impactful and engaging messaging. Thus, practitioners need to have a better understanding of how CSR initiatives are communicated in specific industries (Brammer \& Millington, 2005), and what is most effective among specific audiences.

Professional sport is a multi-billion-dollar industry in the United States, with its lifeblood being the continued engagement of fans. PTSOs are increasingly allocating money to CSR initiatives and the communication of those initiatives, with the specific goal of demonstrating the value of the PTSO to fans and team communities (Babiak \& Wolfe, 2009). The increased importance placed on CSR among PTSOs means an opportunity to research thoroughly how these organizations communicate CSR to create and maintain a symbiotic relationship between the organization and its constituents. Understanding how their CSR choices are currently received by fans is an important part of continued, and effective, community engagement, and social media is an expeditious tool to analyze fan reaction.

Brands and organizations with significant resources and large audiences, such as PTSOs, can greatly impact the lives of citizens (Smith \& Westerbeek, 2007; Abuín-Penas, Babiak, \& Martínez-Patiño, 2020). This content analysis is a practical and functional public relationsfocused thesis that answers foundational questions about public response to CSR messages in the professional sport sector. Moreover, these results can also guide similar industries beyond sport 
including healthcare, hospitality, and entertainment. Then, brands and organizations in these industries could better understand response to their CSR initiatives and increase their return on investment. 


\section{CHAPTER II: REVIEW OF LITERATURE}

\section{Corporate Social Responsibility}

Coombs and Holladay (2012) define corporate social responsibility (CSR) as "the voluntary actions that a corporation implements as it pursues its mission and fulfills the perceived obligations to stakeholders including employees, communities, the environment, and society as a whole" (p. 8). The authors emphasize their definition is focused on voluntary actions and not CSR initiatives mandated by law. Carroll (1979) proposed that organizations' commitment to social responsibility can be divided into four dimensions: "economic, legal, ethical, and discretionary" (p. 499). The discretionary dimension includes voluntary initiatives that go beyond expectations of organizations. This is similar to Coombs and Holladay's (2012) definition. All dimensions of CSR are important considerations for organizations as stakeholders and publics place value in the ability of organizations to contribute to the social good of their communities (Hou \& Reber, 2011). CSR is housed in multiple fields including marketing, business, public relations, and communication.

CSR is becoming less of an option for brands and more of an expectation by publics (Bhattacharya \& Sen, 2004). Bednarska-Wnuk (2015) reported that $77.8 \%$ of organizations consider CSR to be an important part of their company and culture, and this number is only increasing. The social responsibilities that society expects of organizations have evolved from being a personal decision of businessmen to a decision-making process in the 1980's and then as a strategic necessity in the last 20 years (Agudelo, Jóhannsdóttir, and Davídsdóttir, 2020). Some positive organizational outcomes of CSR include creating and strengthening relationships with consumers, enhancing corporate image, and helping societal causes (Wulfson, 2001). 84\% of Americans in a 2004 study said they would switch brands (of relatively equal price) if one brand 
was advocating for a good cause and one brand was not (Bhattacharya \& Sen, 2004). Clearly CSR is important to publics and brands need to integrate CSR initiatives to keep up with competitors. In the professional sport industry competition is obvious among teams, but CSR initiatives can also set teams apart and build and maintain fan bases for individual franchises.

\section{CSR and Professional Team Sport Organizations}

CSR is active in many different business sectors including professional sport (Godfrey, 2009). Professional team sport organizations (PTSOs) are characterized by their operation as a franchise within a professional sport league. Popular leagues in North America include the National Football League, Major League Baseball, National Basketball Association, and the National Hockey League (Pasternak, 2020). The role of CSR in sport is a fairly new research area, with PTSO CSR being explored since the early 2000s.

Although sport is seen largely as an entertainment spectacle, there exists the opportunity for players and teams to enact major societal changes and raise awareness for social issues (Babiak, 2010; Jarvie, 2003; Smith \& Westerbeek, 2007). Although sport is not synonymous with civic engagement, it can act as a space for conversation and action about societal challenges and needs (Jarvie, 2003). Because sport has this unique opportunity, it is vital that team and league executives harness it by facilitating CSR activities and initiatives throughout the various communities which support PTSOs. Sport organizations are beginning to take this responsibility seriously and this is evidenced most recently in the visible support for the Black Lives Matter movement by teams across leagues, but especially in the NBA and the MLB (Andrews, 2020; Associated Press, 2020). 


\section{Internal Motivations for CSR}

Porter and Kramer (2006) identified four reasons for organizations to engage in CSR: "moral obligation, sustainability, license to operate, and reputation" (p. 81). Moral obligation is the belief by owners and executives that the organization simply has a moral duty to engage in ethical business practices. This is certainly an altruistic perspective for any organization to take while implementing CSR. In the professional sport sector this would include organizations assessing the needs of their communities and then responding with efforts to address those needs (S. LaPorta, personal communication, November 24, 2020). Both a pre-assessment of need as well as a post-assessment of how the chosen CSR efforts benefited the community are key components for organizations that adopt a moral obligation approach to CSR (M. Bates, personal communication, November 3, 2020).

Sustainability is the belief that organizations must engage in socially responsible practices that both promote a positive future for the environment and for citizens in society. An organization's license to operate is the notion that organizations have a responsibility to satisfy their stakeholders. This is similar to the moral obligation argument. Organizational leaders harboring this mindset invest in social issues that the organization's stakeholders deem important. The pragmatism of this approach allows for organizations to outsource their moral beliefs to stakeholders which can have consequences such as consumer perception of corporate hypocrisy.

The last reason for CSR as identified by Porter and Kramer (2006) is reputation. This is a major incentive for brands to implement CSR initiatives. Positive effects on brand reputation are major outcomes of CSR, and this is discussed more in-depth later. Likely some organizations identify with one reason while most organizations engage in CSR for a combination of these 
reasons. It is admittedly difficult to assess motivation for CSR and we may only ever know the reported motivations among organizational members. CSR communication is delicate because while stakeholders claim they want to know the initiatives that brands they support are engaging in, they can easily become suspicious of organizational extrinsic motivations for CSR (Du, Battacharya, \& Sen, 2010). Because of this lack of clear understanding of organization motivation, a focus on impact via fan replies on social is appropriate and quantifiable.

The size of an organization has a major impact on what the motivation is to engage in CSR and who decides which initiatives move forward. Large organizations may have executives and owners whose money is being redirected by community relations professionals to solve issues in society that the organization never caused (Shaw \& Post, 1993). This mindset fails to account for the return of that investment back into the organization by way of fan identification. Babiak and Trendafilova (2011) assert that PTSO CSR motivation comes largely from internal and external pressures to be socially responsible. Some pressures might come from organizational members or there may be a pressure to conform if other PTSOs within a league are engaging in specific or substantial CSR initiatives.

The motivations for organizational leaders can and do trickle down to lower-level staff (Misener, Morrison, Shier, \& Babiak, 2020). In the case of PTSOs, athletes can be influenced by the motivation for CSR coming from the top of the team organization. Athletes who perceive their organization to be socially responsible talk favorably about their team to those outside of the organization yielding more favorable fan opinions (Misener, Morrison, Shier, \& Babiak, 2020). Babiak, Mills, Tainsky, and Juravich (2012) suggested that athletes who engage in CSR are both strategic and altruistic about their engagement efforts and their teams'. While the degree 
of both altruism and strategy of CSR can vary among athletes, teams, and leagues, there is some amount of both in every CSR decision that PTSOs make.

All of these engagements are important, and the way that these CSR efforts are shared has a significant impact on fan perception and return of investment (Manheim \& Pratt, 1986). CSR programs can easily fail if organizations neglect to strategize how they share CSR program information across media (Lacey \& Kennett-Hensel, 2016).

\section{Outcomes of CSR}

Porter and Kramer (2006) argue that CSR is vital for organizations because CSR leads to competitive advantage over other organizations. While clear bottom line benefits are difficult to conclude, there are many reasons for organizations to prioritize CSR. The relationship between organizations and society is mutually beneficial because they are interdependent: organizations need competent and healthy individuals to act as consumers and employees, while publics need organizations for goods, services, and jobs. When organizations invest in bettering the communities they serve, they receive benefits from publics. This relationship exists in all organizations in society including sport organizations. The importance of CSR is rarely questioned by researchers; however, the need to understand CSR's specific benefits to organizations and publics remains an important issue (Lacey, Kennett-Hensel, \& Manolis, 2015).

It is impossible to discuss outcomes of CSR without considering the positive financial benefits for organizations (Uzunoğlu, Türkel, \& Akyar, 2017). The link between CSR and financial gain is indirect, but the ability to link CSR implementation to organizational financial performance provides a "strong qualitative foundation to the push for CSR actions" (Joyner \& Payne, 2002, p. 310). Financial gain is only one reason for justifying the need for CSR in any 
organization, but it is important as professional sport is a multi-billion-dollar industry in the United States (Statista, 2021). James and Trail (2008) discovered a connection between fan identification and financial support (i.e., ticket and merchandise sales). When PTSOs use philanthropic initiatives to invest in their communities they develop and strengthen a fan base which can positively affect purchasing decisions by fans (Sheth \& Babiak, 2010). As fans increase in team identification they spend more money supporting the team. CSR initiatives can catalyze fan identification. As organizations engage more with community members, they can receive increased financial support as well as other aspects of support from publics. Financial outcomes are facilitated by strong fan identification, and therefore it is critical for organizations to consider how their fans are identifying with the team.

\section{Fan Identification}

When individuals are a part of a group, they internalize some aspects of that group (Tajfel \& Turner, 1979). Sports fans are symbolically grouped by the teams they support. As groups build and maintain identities they also establish differences between groups (Tajfel \& Turner, 1979). This is easily recognizable for fans of sport teams. At sporting events fans sit and cheer with their respective groups and support their team by dressing the part. College Gameday on ESPN is a great example of this as fans shown in the program are physically separated into groups and show support for their teams by bringing signs and sporting team apparel. This is one of many ways that fans display their team loyalty.

Tajfel and Turner (1979) also established that social groups have hierarchies and are often competitive. Individuals who identify with a group want the group to have prime social status, and individuals can begin to feel threatened if their group social status changes. In the context of sport this is obvious when the team that an individual identifies with is performing 
poorly. When an individual's group social status changes, the individuals may attempt to leave the group for a better one (Tajfel \& Turner, 1979). Another reaction is that group members may try to alter that which is comparative between groups. Changing the focus of the comparison can increase the social status of the group.

Both outcomes are relevant to sport. There is a comparative nature between organizations because, as an individual sees themselves as part of the in-group, they simultaneously see others as the out-group (Ashforth \& Mael, 1989). This competitive nature is obvious in sport. For fans, identifying with a team is positively related to social well-being and feelings of connection (Wann, Waddill, Polk, \& Weaver, 2011). Therefore, fan identification leads to positive benefits for fans as well as the teams they support.

Identification introduces individuals to the ability to derive satisfaction from "activities congruent with the identity" (Ashforth \& Mael, 1989, p. 51). For sport fans this could be gathering for a Super Bowl party or sitting on the same side of a soccer field during a game. Moreover, wearing team apparel and purchasing team merchandise also increases fan identification (James \& Trail, 2008). For franchises, building and retaining a fan base is crucial to organizational sustainability.

Sutton, McDonald, Milne, and Cimperman (2012) propose ways for teams to bolster fan identification. These strategies include increasing team/player accessibility, focusing less on performance-outcomes, creating opportunities for group affiliation and participation, and reinforcing the team's history and tradition (p. 20-21). Scholars have concluded that fan identification is positively related to team success (Boen, Vanbeselaere, \& Feys, 2002; Branscombe \& Wann, 1991; End, Dietz-Uhler, Harrick, \& Jacquemotte, 2002; Fisher \& Wakefield, 1998; Hirt, Zillmann, Erickson, \& Kennedy, 1992). However, there are other ways 
for teams to increase and strengthen fan identification even through losing streaks (Fisher \& Wakefield, 1998; Matsuoka, Chelladurai, \& Harada, 2003; Norris, Wann, \& Zapalac, 2014;). Implementing CSR initiatives is one way to do this. CSR can positively impact fan identification when success is not a viable (or consistent) option for teams.

\section{Brand Loyalty}

Another positive effect of organizational CSR is strengthening relationships with publics. Brand loyalty is an effect of identity (He, Li, \& Harris, 2012) He, Li, and Harris (2012) studied social identity's impact on brand loyalty, and the researchers concluded that brand identification has significant effects on brand loyalty and mediates the effect of brand identity on brand trust and brand loyalty (p. 653). CSR communication is posited to be "a crucial element" for creating and maintaining strong ties between organizations and stakeholders (Chalmeta \& Cortado, 2016, p. 14). Therefore, brand identity (specifically team identity in the present study) is an important research area. Coombs and Holladay (2012) emphasized this point by proposing CSR as an aspect of identification. The social issues that comprise organizational CSR "become the point of identification" between publics and organizations (i.e., sport fans and teams) (p. 34). Therefore, when teams share CSR initiatives that fans identify with, the fan identification with the team increases.

Organizational CSR is a criterion in consumer purchase intentions (Bhattacharya \& Sen, 2004). Fans want to support organizations that value social responsibility. Corporations should implement CSR initiatives both because of principle and to maximize relational value with publics (Lacey, Kennett-Hensel, \& Manolis, 2015). Organizations can be strategic in their CSR implementations while also approaching their initiatives with a sense of goodwill. One way to mesh these two approaches is to partner with organizations that are doing good work in the 
community. If corporations can remove the barrier between their organization and local social sectors their CSR initiatives can be integrated into the community instead of acting as a supplement to social sector efforts to better the public (Sagawa and Segal, 2000). For example, an organization can partner with a local education nonprofit organization to host an event raising money for the local school system. This event would both raise funds for the nonprofit organization and increase favorable public opinion regarding the organization. Businesses are not identities "separate and apart from the society that charters its existence and nurtures its success" (Shaw \& Post, 1993). With this mindset, CSR becomes an extension of the organization into the community and organizational CSR initiatives are tailored to positively impact citizens. Investing in initiatives that support citizens in their communities can increase brand loyalty for PTSOs.

Other authors go further to say that when publics identify with a brand they will take steps to contribute to the success of the brand (Tuskej \& Podnar, 2018; James and Trail, 2008). With respect to social media, publics will engage actively on social platforms with brands that they identify with. Tuskej and Podnar (2018) explain that consumer (i.e., public) brand engagement on social media is an effect of strong public-brand identification. Therefore, social media engagement is a public display of brand loyalty whereas actions like buying merchandise are not. When publics engage with a brand on social media they are displaying that loyalty to others and could encourage others to engage online as well. Thus, sustaining identification should be a top priority of organizations.

PTSO members must be creative to increase and sustain fan identification during lessthan-ideal performance seasons, and an increase in CSR can boost fan identification when teams are both successful and unsuccessful (Matsuoka, Chelladurai, \& Harada, 2003). Melnick (1993) 
proposed initiatives that increase fan-player interaction (which is in line with Suttin, McDonald, Milne, \& Cimperman's (2012) first identification strategy). Assessing fan engagement on Twitter provides a strong link to understanding fan identification among fans. A focus on engagement with CSR content, then, should offer results as to how fans identify with different CSR initiatives on social media. Once executives have this data, they can use it to focus on implementing more CSR initiatives that foster engagement from fans online.

\section{Corporate Reputation}

From a public relations perspective, favorable corporate reputation is critical to organizational success and is a primary motivation for organizations to engage in CSR (Brammer \& Millington, 2005). CSR can positively affect an organization's reputation if the initiatives are genuine (Shim \& Yang, 2016). Publics want organizations to be transparent about their CSR initiatives. Engaging in CSR can mitigate unfavorable public image and increase these positive characteristics, especially for organizations that generally are not regarded positively (e.g., organizations in the tobacco industry) (Brammer \& Millington, 2005). Organizations can engage in CSR proactively to protect their reputation before any crises that could harm their reputation occur (Coombs \& Holladay, 2012). Therefore, CSR tactics are also crises prevention tactics. Moreover, organizational members must consider the industry or sector of their company and adjust their CSR to strategically mitigate unfavorable perceptions. In the sport sector, teams face backlash often, and recovering from scandals is not an easy task (e.g., the Astros trying to regain fan support after the 2017 World Series sign-stealing scandal). According to Fombrun and Shanley (1990), large organizations' level of social concern is a major factor contributing to public perception and corporate reputation. PTSOs must consider this as they contemplate the amount of energy to put into CSR engagements. 
Organizations should choose CSR initiatives that not only align with their values but also align with the values of key external stakeholders and groups (Sen \& Bhattacharya, 2001). Before implementing any CSR initiatives, companies should consider the expected public reactions to increase the likelihood of bolstering public affinity toward the organization. By carefully selecting social initiatives, organizations can simultaneously mitigate negative reactions (Becker-Olsen, Cudmore, \& Hill, 2006). Choosing initiatives that are a good fit between the organization and the public can also have a positive effect on public purchase intention (Barone, Mayazaki, \& Taylor, 2000). In the sport sector this includes mainly an increase in ticket sales and merchandise purchases.

Groza, Pronschinske, \& Walker (2011) asserted the importance of proactive CSR as proactive CSR efforts yield more favorable public perceptions when compared to reactive CSR efforts. According to Gan (2006), companies are often both strategic and altruistic in their giving, but the important measurement is whether fans perceive teams to be genuine in their CSR efforts. Especially when using CSR as a tactic to recover from a tarnished reputation, organizations must be mindful of the possibility of publics assigning corporate hypocrisy to the efforts (Shim \& Yang, 2016). CSR can bolster brand reputation in anticipation of possible crises that could harm that reputation. Public perception is a major measurement by which scholars and organizational employees can determine CSR impact, and it is a fundamental component of CSR analysis in sport. Analyzing fan engagement on CSR tweets provides an opportunity to gauge public perception and draw inferences about specific CSR initiatives' impacts on organizational reputation. 


\section{Sharing CSR Initiatives}

Because corporations cannot meet all stakeholder demands for social responsibility, they must decide which CSR initiatives they will employ and simultaneously decide which initiatives are not worth the organization's energy (Wulfson, 2001). PTSOs “must make CSR tradeoffs, just like other organizations, only theirs tend to be more visible in the media" (Godfrey, 2009, p. 710). Buscarini and Maura (2016) explain that CSR communication is delicate as PTSOs must attempt to communicate CSR in a way that meets expectations of various stakeholders. The reach of PTSOs creates a complex communication environment for sharing initiatives to publics. Sport organizations have significant media coverage because of the large following that teams and athletes acquire, and once corporations decide which initiatives to pursue, they must share that information. The way these CSR initiatives are shared can greatly influence the consumer perception of the organization's social responsibility. Properly articulating CSR initiatives is an increasingly important part of external organizational communication (Verboven, 2011).

Communicating CSR effectively is critical because publics can be skeptical of organizational claims of bettering society, and effective communication can bolster organizational legitimacy and mitigate public skepticism (Bortree, 2014). According to de Bakker and den Hond (2008), sharing CSR initiatives on company websites boosts public acceptance of the organization. Bortree (2014) explained that a main challenge of CSR communication is to present organizational CSR in a way that meaningfully connects the organization's CSR initiatives to "the interests of society" (p. 3). The way these messages are shared can thus impact the way initiatives connect with publics. As technology advances, so do channels of communication, and effectiveness of CSR communication is a vital consideration for organizations seeking to build relationships with their publics through implementation of CSR 
initiatives. Different business sectors approach CSR and CSR communication differently including the professional sport sector. This sector contributes over 70 billion dollars to the U.S. economy annually (Statista, 2021), and has extensive cultural influence as well (Tomlinson \& Young, 2006). Because professional sport is so influential in United States society, an examination of the CSR communication strategies used by professional sport teams is needed. Teams only have so much energy and resources to allocate for CSR, and all teams (but especially smaller teams with less resources than large franchises) want to be sure that the CSR initiatives they are sharing on social media garner positive fan response.

\section{How CSR Initiatives are Shared}

A main platform to share corporate responsibility initiatives is an organizational website. According to a 1998 study by Esrock and Leighty, $82 \%$ of Fortune 500 company websites in the study included information about at least one corporate social responsibility issue. A more recent study by Abitol and Lee (2017) found that $98 \%$ of Fortune 500 companies reference CSR in some way on their corporate websites. CSR messages are becoming more prevalent, and because so many companies are incorporating CSR messages into their websites there is a need to understand the most shared CSR initiatives so that we can assess their impact on publics. For CSR scholars and professionals, organizational websites are key considerations for how to disseminate information to consumers about organizations' CSR initiatives. In the professional sport sector organizations must communicate CSR effectively on their websites because professional sport websites can be updated and changed several times a day to account for game updates and reviews, event promotion, and other new information from around the league.

One aspect of organizational websites that is a developing research area is the interactivity of organizational websites--specifically the opportunity (or lack thereof) for 
consumers to comment and provide feedback about CSR information shared on company web pages (Capriotti \& Moreno, 2007). Capriotti and Moreno (2007) discovered that nearly 70\% of corporations in their 2007 study had a website section dedicated to CSR, but almost none of the organizations' web pages had an option for consumers to provide feedback. This unidirectional communication requires researchers and CSR professionals to gauge feedback in other ways, such as considering engagement across social media. A dialogic use of social media can lead to stronger organizational-consumer relationships and analyzing CSR content across social media can lead to a more strategic use of platforms (Kent \& Taylor, 2016).

The wide adaption of social media in the world allows organizations a cost-effective and straight-forward access point to publics, and organizations can share CSR messages and interact with publics in a way that was not conceivable pre-social media (Etter, 2013; Watkins, 2017). This accessibility to target publics means that social media is a place for public feedback, and the use of social media can act as an additional opportunity for message interactivity. This is unlike the unidirectional nature of PTSO websites. On social media, CSR messages can increase public affection toward an organization and attribution of goodwill (Eberle, Berens, \& Li, 2013; Hayes \& Carr, 2021).

Facilitating an environment where dialogic communication exists, such as social media, allows for stakeholders to be involved in the communication of CSR initiatives which makes CSR messaging more effective (Kent \& Taylor, 2016). Dialogic CSR messaging on social media is an approach that both involves publics in co-creating brand value and leads to positive CSR outcomes (Uzunoğlu, Türkel, \& Akyar, 2017). Because social media interactions about CSR can have these impacts, and because organizational utilization of social media to communicate CSR is becoming more prevalent, it is critical to understand social media CSR message engagement. 


\section{What CSR Initiatives are Shared}

In order to understand how publics respond to CSR information, we must know what initiatives are shared. CSR initiatives are organizational initiatives that focus on a social issue topic (Abitol \& Lee, 2017). Such social issue topics include education, health, environment/energy, and diversity. Hou and Reber (2011) propose that most organizations engage in CSR because it is expected. Stakeholders value CSR and therefore organizations often strive to make it a priority. CSR initiatives should be tailored to reflect and match core organizational activities (i.e., organizations should engage in CSR initiatives that are related to their business goals and practices) (Lunenberg, Gosselt, \& De Jong, 2016). This perceived CSR fit by consumers can impact how these initiatives and the organizations are framed by the media. Organizations whose initiatives are in line with the organization's general goals (e.g., a gym hosting a $5 \mathrm{k}$ for charity) are generally framed positively in the media when compared to organizations that employ CSR initiatives that are not related to the organization (e.g., a bakery hosting a volleyball tournament for charity) (Sheath \& Babiak, 2010). The same principle applies to sport organizations, and PTSOs should consider fit when brainstorming new CSR ideas. CSR is more effective if it is related to the activities and goals of the PTSO. If publics perceive a team and its CSR engagement(s) to be a bad fit, they may feel negatively about the organization (Becker-Olsen, Cudmore, \& Hill, 2006; Coombs \& Holladay, 2012).

Andrassy \& Bruening (2011) analyzed how community engagement initiatives are shared on NCAA Division I athletics. Their findings suggest that larger schools in larger divisions allocated more of their website to CSR and appeared to be more engaged in their service than lower-level athletes and divisions. Because PTSOs are larger than collegiate teams we can assume that PTSO CSR engagement is significantly greater than that of college teams, and thus 
an in-depth analysis of the initiatives are shared on PTSO websites is important. There is a need to understand what CSR initiatives are shared on PTSO websites so team and league executives can use that information to make CSR decisions. For example, if $80 \%$ of NFL teams are separately engaging in environmental CSR initiatives, perhaps the league should consider creating a league-wide CSR green agenda. Doing so would allocate more resources toward the cause creating a bigger impact in the country. Also, most of the league would support the green agenda seeing as most of the teams were already focused on green CSR. RQ1 poses a foundational question:

RQ1: Which CSR initiatives are most often shared on professional team sport organizations' websites across the four major PTSOs in the United States?

\section{Engagement}

Fan perception about organizational CSR is vital when organizational members are deciding what initiatives to implement. After organizational messages about CSR are created and shared, organizational members must assess the impact of those messages. Organizations should tailor their CSR to fit the needs of the community and the expertise of the organization (Bhattacharya \& Sen, 2004; Sen \& Bhattacharya, 2001). Fan reactions provide insight as to what CSR initiatives are engaging fans and therefore what initiatives are worth investing in.

Public-brand engagement is a key part of organizational communication as publics have diverse perspectives and want organizations to be open to interaction with them (Johnston, 2014). Since the rise of social media, consumers now have the opportunity to interact with brands and organizations by liking, re-tweeting, commenting, sharing, and otherwise participating on social networking sites. Brodie, Ilic, Juric, and Hollebeek (2013) define 
engagement as interaction "between consumers and the brand, and/or other members of the community" (p. 107). Organizations must appropriately and effectively communicate their CSR initiatives to increase positive public perception. The antithesis of this notion is that poorly communicated CSR messaging on social media can and will negatively affect organizational reputation as perceived by publics. Public engagement also is a "relational exchange" (p. 107) between publics and brands. Organizations communicate their CSR initiatives and outcomes as a way to continually foster the organization-public relationship (Devin \& Lane, 2014). Okazaki, Plangger, West, and Menendez (2020) explain that this relational exchange on social media is an opportunity to co-create value with brands online.

This engagement provides an insight into public perception and, in the context of professional sport, fan perception of teams and leagues. Thus, researching engagement patterns surrounding CSR posts provides insight into how fans respond to CSR initiatives. Barone, Mayazaki, and Taylor (2000) and $\mathrm{Wu}$ and Tsai (2007) found that there is a positive relationship between positive consumer perception of organizational CSR and purchase intention. This correlation is significant as an obvious main goal of PTSOs is to increase ticket and merchandise sales. As a billion-dollar industry, professional sport is clearly concerned with financial success, and this connection bolsters the practicality argument for investment in organizational CSR. A critical step, then, is to identify what CSR initiatives yield the greatest fan engagement on social media.

Yang, Basile, and Letourneau (2018) assert that social media platform use must be considered when analyzing CSR messages. For the present study, Twitter is an appropriate platform for analysis. Twitter data provides the opportunity for a clear and measurable analysis of engagement on social media by sport fans. Moreover, as of July 24, 2020, Twitter has 326 
million active users making it rich with data (Statista, 2020). An analysis of the likes, retweets, and responses on PTSO tweets about CSR should provide insight into which types of CSR initiatives yield significant engagement via social media. It is necessary to analyze the valence of fan replies on Twitter when researching engagement because positive fan replies display support for the CSR topics mentioned in the team's tweet. It is important to separate positive replies from negative replies and then include positive replies along with likes and retweets in the engagement analysis.

RQ2: What is the reply valence for each CSR topic shared on Twitter?

Once we develop an understanding of the CSR initiatives that yield the most engagement on Twitter, we can analyze specific messages to better understand what CSR topics lead to the most engagement. One characteristic that should be analyzed is the degree to which the initiatives are action-oriented. Action-oriented initiatives are hands-on and could include visits to hospitals, volunteering at a local shelter, or delivering books to children in need. Initiatives that are not action-oriented are awareness initiatives. These are hands-off and may include donating funds or offering support from a distance or online. Because PTSO stakeholders (of which the fan base is a large portion) expect teams to meet stakeholder standards for effective social responsibility, it is important that team executives are cognizant of stakeholder expectations (Babiak \& Kihl, 2018). According to Babiak and Kihl (2018), the relational value of CSR is vital to increase fan engagement with the team, and therefore it would be helpful and practical to understand if action-oriented CSR initiatives have a better engagement response online than nonaction-oriented activities. To address this, I introduce another research question: 
RQ3: Do action-oriented or awareness CSR initiatives shared on social media garner more positive engagement?

Another characteristic to consider for CSR is how targeted CSR efforts are to organizations' communities. Some initiatives are very community-specific such as mulching parks in community neighborhoods. Not community-specific initiatives are more wide-reaching such as hosting a shopping spree for children in foster care. Building a fan base is a main goal of PTSOs, and strategic community engagement fosters this (Heere \& James, 2007). Most PTSOs initially begin community engagement work to increase fan-team identification and to mitigate fan departure when the team is not competitive or successful. According to Heere and James (2007), teams initially focus on their local communities and then begin to expand efforts outside of their local area. Branscombe and Wann (1991) propose that fans who are outside of the geographic area of their chosen team may have less feelings of identification because they are less likely to build comradery with other fans of that team. Geographic location impacts feelings of identification because of the presence or lack of other like-minded fans. This could affect engagement on tweets sharing community-specific initiatives and tweets sharing non-community specific initiatives. Because fan engagement online is a measurable activity that is impacted by fan identification (James \& Trail, 2008), it is important to include an analysis of the fan engagement related to posts about local and non-local PTSO CSR initiatives.

RQ4: Will CSR initiatives specific to PTSOs' communities have more positive fan engagement than initiatives that are not community-specific? 
One final characteristic worth exploring is the commitment level of the CSR initiatives shared on social media. Greenwood (2007) proposed the difference between high commitment and low engagement organizational initiatives to engage stakeholders (p. 317, p. 322). Babiak and Trendafilova (2011) adopted these terms and applied them to PTSO CSR. In the context of sport and community engagement, high commitment initiatives are long-term commitments that need to be sustained by the organization and require resources to do so (e.g., financial resources or technology). Initiatives that are low engagement are short-term and do not require substantial resources to sustain the initiative. Examples of high commitment initiatives include transition of stadium lighting to all LED and development of long-term education programs to support local schools. Some examples of low engagement initiatives include hosting a Thanksgiving dinner for community members and handing out school supplies before the first day of school.

The difference in fan engagement responding to these two types of CSR is an interesting consideration as there is presumably a different degree of spectacle between the two types of CSR and how their posts may be seen by fans on social media. High commitment initiatives are likely less of a spectacle than low engagement because low engagement initiatives only require a large amount of energy for a short period of time, so the energy put into the activity is extremely condensed (Babiak \& Trendafilova, 2011). However, this does not necessarily mean that fans respond more to one type of commitment on social media, and this question remains unanswered in scholarship. Thus, I present a final research question:

RQ5: Will CSR initiatives that are high commitment have more or less positive fan engagement than low engagement initiatives? 


\section{CHAPTER III: METHODS}

The purpose of the study was to both determine the topic of and analyze the relationships between tweets highlighting various CSR initiatives of professional team sport organizations (PTSOs) and fan engagement on Twitter. A quantitative content analysis is the most appropriate research method as this method allows researchers to "provide aggregate accounts of inferences from large bodies of data that reveal trends, patterns, and differences" (Krippendorff, 1980, p. 404). Moreover, content analyses are systematic and objective (Riffe, Lacy, \& Fico, 2014). Also, previous researchers have found content analysis to be an effective method to study CSR communication (Abitol \& Lee, 2017; Abuín-Penas, Babiak, \& Martínez-Patiño, 2020; Andrassy \& Bruening, 2011; Campopiano \& Massis, 2016; Wang \& Gao, 2016). Quantitative content analyses allow researchers to analyze large amounts of content in a relatively short timeframe compared to qualitative content analyses. Also, because researchers are not involved in the coding process and instead train independent coders to code units, researchers can draw conclusions about the data without getting involved in the communication process that is being analyzed (Riffe, Lacy, \& Fico, 2014). Since the goal of this study is to identify differences of engagement in response to existing content, CSR tweets for many teams across multiple professional sport leagues, this method is appropriate. Conducting a content analysis includes unitizing data, coding it, and analyzing and drawing inferences (Riffe, Lacy, \& Fico, 2014).

\section{Sample}

These data were collected during the COVID-19 pandemic. Although a lack of in-person engagements certainly affected the type of CSR activities that PTSOs engaged in and thus the messages that were shared on social media, the pandemic offered an opportunity for researchers to engage in insightful research on CSR during crises and "potentially catalyse a new era of CSR 
development in the long run" (He \& Harris, 2020, p. 181). Scholars have called for an increase in research about CSR communication during crises to better understand how CSR in the professional sport sector will evolve post-COVID-19 (Abuín-Penas, Babiak, \& Martínez-Patiño, 2020). Because sport can be a lens through which individuals make sense of the world, sport also has the unique opportunity to be vehicle for social change, especially during times of crises (Inoue \& Havard, 2015).

Moreover, COVID-19 has highlighted systemic issues in our society and exacerbated inequities in all areas of life. Examples of this are increased economic disparity, increased stigma among certain populations (notably Asian Americans as the COVID-19 virus originated in Asia), and increased risk of adverse psychosocial outcomes like depression and anxiety (Pfefferbaum \& North, 2020). This new exposure allows for novel opportunities for CSR engagement and research (Abuín-Penas, Babiak, \& Martínez-Patiño, 2020). As the pandemic and societal injustices of 2020 highlighted the need for organizational CSR, CSR developments in the longterm will be hinged on how organizations managed this turbulent time (He \& Harris, 2020).

\section{Part 1}

Tweets were collected to discover the most frequently shared CSR tactics on PTSO websites. Choosing a sample for analysis was two-fold. First, four teams from each of the four most popular leagues in the United States according to Pasternak (2020) were randomly selected: The National Football League, National Basketball Association, Major League Baseball, and National Hockey League. Each team in the NFL was assigned a number from 1-32 and a random choice generator was employed to select a number from the list at random. That program was run four times to achieve four NFL teams at random. The same process was followed for each of the three remaining leagues, assigning numbers to each team, using a program to randomly select a 
number, and repeating the program three times for a total of four teams. The final sample of teams was $N=16$ selected randomly across the four leagues. The date of data collection was October 24, 2020 to coincide with the timeframe in Part 2. Archive.org was used to archive the webpages so that the date of units on team webpages analysis was consistent across all teams.

In coder training two coders without knowledge of the research questions analyzed CSR topic of units on PTSO webpages. The researcher did not code the data to avoid researcher bias. Coder training was conducted following a codebook (Appendix) adapted from Abitol and Lee (2017). The authors conducted a similar content analysis of CSR messages, and they categorized CSR messages into 11 main topics. Those authors defined "topic" as "the issue that CSR activities focused on" (p. 800). The authors' topics are clear and detailed, and therefore their definition of topic and their codebook were applied for the present study. Abitol and Lee's (2017) topics were "education, health, research and development, business development, safety, environment/energy, finance, religion, public policy, employee/workplace engagement, and diversity" (p. 800). The teams' CSR initiatives that were shared on their community pages were coded by these topics.

The pages were coded by the same two coders separately. The units of content from each team's community pages were exported into a spreadsheet by the researcher to ensure consistency across the units for the two coders. Coders were trained on the categories using a training sample of webpage units archived on 11/5/2020 from four randomly selected PTSOs not included in the actual sample — one from each major league $(n=53)$. Coders were trained on these categories, and the intercoder reliability for CSR topic was established in the Part 2 pilot sample since the categories from Parts 1 and 2 were identical. 
Once initial reliability was established, the coders coded units from webpages archived on 10/24/2020 for CSR topic for the 16 teams in my sample. Each coder coded half of the webpage units $(n=84 ; N=168)$

After the 16 teams' community pages were coded, the next step was to compare the teams and determine what CSR topics are most frequently shared on community webpages across all the teams. Doing this provided an understanding of what topics of CSR initiatives PTSOs most often shared with their publics.

\section{Part 2}

The second part of this study was an analysis of fan engagement on Twitter. The goal was to discover any relationship between the content and message of CSR tweets presented in the research questions and fan engagement. Tweeting is one way for publics to interact with organizations and a way for organizations to gauge public engagement with the brand (Kang, 2014; Men \& Tsai, 2014). Twitter provides an opportunity for teams and fans to interact with one another, and Twitter is a platform that organizations use regularly to share CSR communication (Chalmeta \& Cortado, 2016). Twitter has 326 million users as of July 2020, providing ample data for analysis (Statista, 2020). Engagement on Twitter is possible through likes, retweets, and replies (Men \& Tsai, 2020). On Twitter, replies offer often rich accounts of public perception compared to the more basic metrics of likes and retweets. I selected a 30-day timeframe for analysis as 30 days provides sufficient data for analysis across the 16 teams in the study. The data was extracted using rtweet, a software that collects Twitter data (Kearney, 2019). To select the month for analysis several factors had to be considered. Since this research was done during the height of COVID-19 I chose a 30-day timeframe where all four leagues in the 
study were actively playing: October 1-October 30, 2020. This provides a consistent context across all leagues for analyzing CSR messages.

The coding for Part 2 of this study employed the use of the same independent coders as the coders were already familiar with the coding process and the categories used. The same CSR categories from Abitol and Lee (2017) that were used in Part 1 of the study were employed in Part 2 (Appendix). A pilot sample of CSR tweets from 11/5/2020 from four PTSOs (one from each league) not included in the sample was used to test reliability $(n=150)$. Initial reliability was established $(k=.744, p<.001)$. Then, the coders coded $20 \%$ of the actual sample for CSR topic $(n=52)$, and initial intercoder reliability was confirmed $(k=.755, p<.001)$. This level of agreement satisfied reliability for the CSR topic variable for both Parts 1 and 2. Once reliability was confirmed, the coders each coded $40 \%$ of the sample independently $(n=102)$.

Next, coders coded each unit in the pilot sample as being action-oriented (1) or not action-oriented (2). Coder retraining with another pilot sample was needed to reinforce understanding of the coding categories between the independent coders. Two rounds of coder retraining were sufficient for the coders to reach agreement on all the codes' definitions. In the second round of coder training with the second pilot sample it was clear that the units in the pilot sample were almost exclusively not action-oriented and very few were coded as action-oriented. Because of this the units were too homogeneous to do an analysis on this variable.

Then, they coded units as being low engagement (1) or high commitment (2). Again, coder retraining was needed to reach agreement on how to define the codes to effectively code the samples. After two rounds of coder training it became clear that most of the tweets were low engagement as opposed to high commitment. This homogeneity again meant this variable could not be effectively analyzed in the actual sample. 
Then, they coded the pilot sample units as being community-specific (1) or not community-specific (2) and reliability was established after three rounds of coder training $(n=$ $149, k=.957, p<.001)$. Throughout retraining the definitions were re-worked to increase understanding between the coders (Appendix). After confirming initial reliability, the coders coded $20 \%$ of the actual sample $(n=52)$ to establish final reliability $(k=1, p<.001)$. Once reliability was confirmed, the coders each coded $40 \%$ of the sample independently $(n=102)$.

Next, all the replies to tweets in the sample were coded as having a negative valence (-1), a neutral valence (0), or a positive valence (1). The researcher first went through all replies of tweets in the sample and only selected replies that were about the tweet for analysis. Replies that were unrelated to the original tweet were not included in the sample. For example, some replies to CSR messages were tweets encouraging users to follow a specific account, and the replies were not at all related to the CSR tweet. These replies were not included in the sample of units for analysis. All relevant replies were exported into a spreadsheet to ensure that the coders' units for analysis were consistent. Then, the coders coded pilot samples and reliability was established after three rounds of coder training $(n=149, k=.988, p<.001)$. Then, the coders each coded $20 \%$ of the actual sample to confirm reliability $(n=52)$. Once reliability was confirmed $(k=$ $.969, p<.001)$, the coders each coded $40 \%$ of the sample independently $(n=102)$.

The following results answer the research questions and in doing so, provide insights into the type of CSR message shared on social media and fan response to CSR messages. 


\section{CHAPTER IV: RESULTS}

In Part 1, a total of 168 units from PTSO webpages were analyzed from 16 total teams, 4 each from the NFL, MLB, NBA, and NHL. In Part 2, a total of 256 tweet units were analyzed from those same 16 teams tweeted from October 1-30, 2020.

The present study set forth five research questions to better understand CSR messages shared by PTSOs on Twitter and fan response to those messages. Chi-square analyses were run for these variables to determine CSR topic frequency distribution to answer the research questions.

The first research question asked if there was a significant frequency difference in CSR topic on PTSO community webpages. For RQ1, a chi-square was conducted to assess whether a significant difference in frequency existed in type of CSR topic shared on PTSO community webpages in the sample. There were 11 categories implemented for coding; however, three categories were not utilized by the coders (i.e., Safety, Religion, and Research and Development). The coders determined that no units present in the sample fit into these three categories. Therefore, the chi-square was conducted using the eight utilized categories. The

result for this test was significant: $\chi^{2}(7, N=168)=138.19, p<.001$. See Table 1 for these frequencies. 


\section{Table 1}

Frequency of CSR Topic on PTSO Community Webpages

\begin{tabular}{lll}
\hline CSR Topic & $n$ & Valid \% \\
\hline Health & 57 & 33.9 \\
Education & 37 & 22 \\
Finance & 30 & 17.9 \\
Diversity & 29 & 17.3 \\
Environment/Energy & 6 & 3.6 \\
Public Policy & 5 & 3 \\
Employee/Workplace & & \\
Engagement & 3 & 1.8 \\
Business Development & 1 & .6 \\
Total & 168 & 100 \\
\end{tabular}

For RQ2 regarding CSR topic frequency for PTSO tweets and reply valence, first a chisquare was conducted to assess whether there was a significant difference on Twitter of CSR topic. Results were significant: $\chi^{2}(7, N=256)=200.75, p<.001$. Three CSR topics were not coded as present in the dataset by the coders: Energy/Environment, Research Development, and Religion. See Table 2 for these frequencies. 
Table 2

Frequency of CSR Topic on PTSO Twitter Accounts

\begin{tabular}{lll}
\hline CSR Topic & $n$ & Valid \% \\
\hline Public Policy & 82 & 32 \\
Finance & 58 & 22.7 \\
Diversity & 52 & 20.3 \\
Health & 37 & 14.5 \\
Education & 21 & 8.2 \\
Business Development & 3 & 1.2 \\
Employee/Workplace & & \\
Engagement & 2 & .8 \\
Safety & 1 & .4 \\
Total & 256 & 100 \\
& & \\
\hline
\end{tabular}

Next, a chi-square was conducted to assess whether there was a significant difference in reply

valence to CSR tweets. The result for this test was significant: $\chi^{2}(2, N=256)=68.92, p<.001$. See Table 3 for valence frequencies. 354 individual replies were coded. 
Table 3

Reply Valence to CSR Tweets

\begin{tabular}{lll}
\hline Valence & $n$ & Valid \% \\
\hline Positive (1) & 101 & 39.5 \\
Neutral (0) & 130 & 50.8 \\
Negative (-1) & 25 & 9.8 \\
Total & 256 & 100 \\
\end{tabular}

To answer RQ2 a frequency test was run to understand reply valence of CSR topic. See Table 4 for a breakdown of these relationships. 


\section{Table 4}

Reply Valence to CSR Topic on Twitter

\begin{tabular}{|c|c|c|c|c|c|c|c|c|}
\hline \multirow[t]{2}{*}{ CSR Topic } & \multicolumn{2}{|c|}{ Positive Replies } & \multicolumn{2}{|c|}{ Neutral Replies } & \multicolumn{2}{|c|}{ Negative Replies } & \multicolumn{2}{|c|}{ Total } \\
\hline & $n$ & $\%$ & $n$ & $\%$ & $n$ & $\%$ & $n$ & $\%$ \\
\hline Public Policy & 23 & 28.4 & 50 & 61.7 & 8 & 9.9 & 81 & 100 \\
\hline Finance & 31 & 54.4 & 22 & 38.6 & 4 & 7 & 57 & 100 \\
\hline Diversity & 25 & 48.1 & 25 & 48.1 & 2 & 3.8 & 52 & 100 \\
\hline Health & 17 & 45.9 & 13 & 35.1 & 7 & 18.9 & 37 & 100 \\
\hline Education & 4 & 18.2 & 16 & 72.7 & 2 & 2 & 9.1 & 100 \\
\hline $\begin{array}{l}\text { Business } \\
\text { Development }\end{array}$ & 0 & 0 & 2 & $66.7 \%$ & 1 & 33.3 & 33 & 100 \\
\hline $\begin{array}{l}\text { Employee/ } \\
\text { Workplace }\end{array}$ & & & & & & & & \\
\hline Engagement & 0 & 0 & 1 & 50 & 1 & 50 & 2 & 100 \\
\hline Safety & 0 & 0 & 1 & 100 & 0 & 0 & 1 & 100 \\
\hline Total & 101 & 100 & 130 & 100 & 25 & 100 & 256 & 100 \\
\hline
\end{tabular}

For RQ4 regarding the reply valence to community-specific and not community-specific tweets from PTSOs first a chi-square was conducted to assess whether there was a significant difference in community-specific or not community-specific initiatives shared on Twitter. The 
results for this test were significant: $\chi^{2}(1, N=256)=121, p<.001$. See Table 5 for these frequencies.

\section{Table 5}

Frequency of Community-Specific Tweets

Community-Specific or Not $\quad n \quad$ Valid $\%$

\begin{tabular}{lll}
\hline Community-Specific & 40 & 15.6 \\
Not Community-Specific & 216 & 84.45 \\
Total & 256 & 100 \\
\hline
\end{tabular}

To answer RQ2 a frequency test was run to understand reply valence of CSR topic. See Table 6 for these frequencies.

\section{Table 6}

Reply Valence to Community-Specific Tweets

$\begin{array}{lllll}\text { Community-Specific } & \text { Positive } & \text { Neutral } & \text { Negative } & \text { Total } \\ \text { Or Not } & \text { Replies } & \text { Replies } & \text { Replies } & \end{array}$

\begin{tabular}{llllllll}
\hline$n$ & $\%$ & $n$ & $\%$ & $n$ & $\%$ & $n$ & $\%$
\end{tabular}

$\begin{array}{lllllllll}\text { Community-Specific } & 13 & 33 & 21 & 52 & 6 & 15 & 40 & 100 \\ \text { Not Community- } & 88 & 41 & 109 & 50 & 19 & 9 & 216 & 100 \\ \text { Specific } & & & & & & & & \end{array}$

$\begin{array}{lllllllll}\text { Total } & 101 & 100 & 130 & 100 & 25 & 100 & 256 & 100\end{array}$


RQ3 and RQ5 were unable to be answered because of the homogeneity of responses that excluded the possibility for analysis. 


\section{CHAPTER V: DISCUSSION}

The professional sport sector's influence has evolved, and PTSOs are considered leaders in their communities in addressing societal issues (Babiak \& Wolfe, 2009). This was clear in PTSO CSR efforts in 2020 (Abuín-Penas, Babiak, \& Martínez-Patiño, 2020). What is still unclear in scholarship is the extent to which specific types of CSR messages on social media contribute to PTSO longevity, evidenced by public perception on social media. The present study sought to examine the CSR topics shared by PTSOs on community webpages and on Twitter. Also, this study aimed to understand reply valence to these topics as well as CSR tweets that were specific to the community or not specific to the community. To address RQ1, RQ2, and RQ4, the results of this study indicated that there were significant differences in frequency of topic, significant differences in frequency of community-specific and not community-specific tweets, and significant differences in frequency of reply valence to CSR tweets across media.

\section{CSR Topic}

Findings indicated that there were significant differences between CSR topics shared on each PTSO's community webpage. There were also significant differences between CSR topics shared on PTSO Twitter accounts. Additionally, the CSR topics shared on community webpages were largely different than those CSR topics shared on Twitter. For example, the top three most frequent CSR topics shared on community webpages in the sample was Health, Education, and Finance, whereas on Twitter the top CSR topics were Public Policy, Finance, and Diversity. This could be evidence of PTSOs critically considering platform choice regarding CSR content (Yang, Basile, \& Letourneau, 2018). While Twitter is a commonly-used platform to communicate CSR, it may be most effective to use Twitter when communicating specific CSR topics. 
Twitter has the potential to be a highly dialogic platform whereas PTSO webpages are communicatively unidirectional (Capriotti \& Moreno, 2007; Yang, Basile, \& Letourneau, 2018). Public backlash, or simply negative feedback, is likely (and common) on social media platforms like Twitter, but CSR content can be posted on a team webpage without serious fear of negative backlash. While fan engagement is an important component for building relationships and fan identification (Sutton, McDonald, Milne, \& Cimperman, 2012), negative engagement on social is an indication of fan de-identification and this could possibly impact the feeling of identification for fans who witness those negative social media interactions.

Previous research asserts that CSR content should be relevant to the platform and conversations on that platform (Abitol \& Lee, 2017). Public Policy tweets were the most common topic on Twitter in the sample, with many of these messages regarding voter registration preceding the 2020 presidential election. The second most common topic on Twitter was Diversity. Any organization should consider platform choice, as the communication of "certain dimensions of CSR activity," in other words certain CSR topics, could be more effective on specific platforms (Yang, Basile, \& Letourneau, 2018, p. 17). This could be evidence of PTSOs sharing these CSR initiatives on Twitter because that is where conversation about Public Policy and Diversity issues are rich and welcome.

Along with CSR topic relevance on the chosen platform, another consideration is the longevity of content on community webpages compared to how content is easily and quickly buried on Twitter by new tweets. A CSR tweet can become buried by 30 other tweets over the course of a single game. An important question, then, is whether PTSOs take this into consideration. With conversations about politics often regarded as controversial, especially in 2020 in the United States, Twitter was a strategic place for these initiatives to be shared because 
a civic engagement tweet that receives backlash does not live on the platform long before it is buried in tweets about game statistics and team updates. The same argument could be made about diversity initiatives shared on social media. So, if the general conversation on social media about these topics turns from positive to negative and the PTSO CSR messages about those topics are no longer welcome, these PTSO messages are buried by other tweets quickly. In other words, it may be safer to tweet controversial CSR initiatives than it is to share those initiatives on team community webpages.

\section{Engagement}

Engagement on social media is a critical metric to gauge public perception of an organization and of organizational initiatives (Brodie, Ilic, Juric, \& Hollebeek, 2013). On Twitter, replies offer rich accounts of public perception. In the present study, negative feedback was rare overall, with reply valence in this sample mostly neutral (50.8\%), followed by positive (39.5\%) and then negative (9.8\%). Overall, publics take a major part in asserting CSR importance through their engagement online (Okazaki, Plangger, West, and Menendez, 2020). Fans contribute to creating a taxonomy of CSR importance through their replies, and the results indicate that Finance, Health, and Diversity initiatives were most important, as those topics had the highest percentage of positive replies. Employee/Workplace Engagement received the highest percentage of negative replies deeming it the least important topic in the sample. Moreover, fans who engage by replying positively are publicly displaying their identification with the organization.

For community-specific and not community-specific tweets the breakdown of reply valence was similar for both and therefore neither one was more positively-received than the other. This is an important finding as Brann and Wanscombe (1991) argued that fans outside of 
the geographic region of their chosen team may have less feelings of identification than those fans who reside in the team's geographic area. Understanding that social media engagement is an example of fan identification (James and Trail, 2008; Tuskej \& Podnar, 2018), this finding asserts that availability of online communication has likely blurred the geographic constraints of fandom in the professional sport sector. If fans are replying positively to initiatives that are specific to the team's community and not specific to the team's community, it could be an effect of fans accepting that geography no longer dictates which team fans are allowed to support.

When fans identify with PTSOs, they experience benefits including feelings of connection to the team and other fans (Wann, Waddill, Polk, \& Weaver, 2011). This is true for fans of all four leagues in the sample of the present study. Identification is an obvious effect of PTSO success; however, teams can continue to build fan identification during losing seasons and off seasons (Norris, Wann, \& Zapalac, 2014). There were 256 tweets and 354 relevant replies in the sample so there was a generous number of replies from which to draw inferences. The present study concurs that fans may display identification by engaging with CSR messages on Twitter by replying with their thoughts about the initiatives.

The two research questions that could not be answered were omitted because of a realization of the homogeneity of responses during coder training. RQ3 sought to uncover the reply valence on tweets sharing action-oriented or not action-oriented CSR initiatives. Not action-oriented initiatives (e.g., donations or sponsorships) are a major way for PTSOs to contribute to their communities, but these types of initiatives are often less visible than actionoriented initiatives (e.g., meet and greets or basketball camps). Stakeholder expectations must be considered when planning initiatives (Babiak and Kihl, 2018), and level of action-orientation would be an interesting variable to consider. Because the connection between reply valence and 
action-oriented or not action-oriented initiatives remained unanswered in scholarship, RQ3 hoped to address that gap in research. Certainly, the COVID-19 pandemic decreased the number of action-oriented initiatives for PTSOs in 2020, and it is probable that this variable could be analyzed in more normal times.

RQ5 could also not be analyzed because of a homogeneity of responses. This question sought to understand the reply valence responding to tweets that were low engagement (short term, high energy initiatives) compared to high commitment (long-term initiatives that require long-term investment of organizational resources) (Babiak \& Trendafilova, 2011; Greenwood, 2007). After multiple rounds of coder training it became clear that most of the tweets were referring to low engagement initiatives compared to high commitment. It is possible that the amount of high commitment initiatives was influenced by the pandemic, but it is also probable that PTSOs generally choose to focus on initiatives that are low commitment and flashy like a $5 \mathrm{k}$ run for charity, as opposed to high commitment initiatives that make a difference long-term but perhaps are not as easy to sell to an audience online, such as rewiring a stadium to decrease a team's carbon footprint.

Online engagement is evidence of identification (James \& Trail, 2008), and when PTSOs experience an increase in fan identification, they can expect benefits including an increase in brand loyalty, corporate reputation, and, perhaps most importantly, financial outcomes (Bhattacharya \& Sen, 2004). Therefore, an understanding of what CSR messages spark identification, evidenced by social media engagement, is critical for organizational success and longevity. 


\section{Practical Implications}

The present study presents findings that could better public relations practitioners' ability to connect with publics on social media and strategically implement CSR initiatives that benefit the organization as well as community members. Previous scholars have concluded that CSR is critical for organizations as it provides them with a competitive advantage over others in their sector (Agudelo, Jóhannsdóttir, and Davídsdóttir, 2020; Bhattacharya \& Sen, 2004; Porter \& Kramer, 2006; Wulfson, 200). Therefore, these findings provide practical suggestions for community relations and public relations teams to better understand the CSR content that connects with their communities and positions the organization positively in their sector.

The findings of RQ2 and RQ4 provide suggestions as to which CSR topics are most well received and least well-received by fans across leagues in the United States. Therefore, PR practitioners can strategically share CSR messages about initiatives they can expect will be received most favorably by their fans. Also, RQ4 posits that there is little distinction between whether fans respond more positively to community-specific initiatives or not communityspecific initiatives. So, PR practitioners should not concern their organizations will strategically choosing which type of initiative to share on social media.

Practitioners in the PTSO CSR field can use these findings to increase their return of investment from strategic CSR. It is important for PTSO PR practitioners to understand what their community values. The truest and most altruistic form of CSR is addressing the needs and values of community members through PTSO engagement initiatives (S. LaPorta, personal communication, November 24, 2020). Moreover, networking with stakeholders is a crucial element of PTSO CSR to ensure that engagement initiatives are well-received and supported by fans, stakeholders, and donors (M. Bates, personal communication, November 3, 2020). 
Major outcomes of a more strategic implementation of CSR messages include an improvement in corporate reputation (Brammer \& Millington, 2005; Shim \& Yang, 2016) that draws fans and a reputation that pre-emptively mitigates negative effects of organizational crises (Coombs \& Holladay, 2012). The present study provides practical suggestions for PTSOs to strategically engage with their communities in ways that will have long-term benefits.

\section{Limitations}

There are some limitations in the present study that should be noted. Most obvious is the timeframe of data collection. The present study was completed during the COVID-19 pandemic and, while data was collected during an active season for all four leagues, the restrictions put forth by national health guidelines impacted the type and amount of CSR initiatives that teams could engage in in 2020 and thus impacted CSR messaging. Another sampling limitation is that many PTSOs have separate Twitter accounts where they only tweet CSR messages. While this was noted before the study began, not all teams have separate accounts and, therefore, it was deemed more appropriate to focus on main PTSO Twitter accounts.

Another timeframe limitation was the election cycle during data collection. Because November $3^{\text {rd }}$ was election day in the United States, messaging about voter engagement and voter turnout was common on all social media platforms in October. This includes PTSO social media outlets. If data were collected not during an election cycle it is likely that the sample would have consisted of less public policy tweets.

Another limitation is the choice to utilize main PTSO Twitter accounts as opposed to CSR-dedicated PTSO accounts. Abitol and Lee (2017) argued that CSR-dedicated pages on social media give organizations the opportunity to focus on CSR specifically instead of including CSR messages in their general organizational social media feed. The authors found that 
stakeholders are more likely to engage with messages on CSR-specific pages than on nonspecific pages. While these findings were considered, the present study focused on CSR messages shared on PTSO general Twitter accounts because not every team has a separate CSRdedicated account. This likely lessened the number of overall CSR messages included in the sample.

A final consideration is the variation of team success in the sample. The present study utilized random sampling to select the teams; therefore, the methodology controlled for this variable, but there was a variation of success that was naturally occurring among teams. Teams with more rabid fanbases, or vocal opposition, and successful records may see different responses than teams with poor records. Teams that are successful generally receive more positive feedback across media (Branscombe \& Wann, 1991). This can be expanded to include modern social media engagement. When teams are less successful they receive less favorable comments online. Moreover, fans of one team may have responded negatively to CSR tweets by rival teams simply because they are the rival team. While these confounding variables should be considered when reading the present study, the results indicate that most replies were positive or neutral; therefore, it is believed that measure of team success did not greatly affect results. In the future, scholars could account for this variable by using team success as a covariate to better understand its impact on CSR messaging and fan response. Additional future research can also expand on the present study's findings.

\section{Directions for Future Research}

Much research is still needed on this topic, especially as CSR becomes even more commonplace for PTSOs and as fans' expectations of PTSO CSR evolves. This study provides some foundational data regarding frequency of types of CSR messages on social media; 
however, future scholars could use this study as a guide when researching samples that would provide more nuanced insights. Scholars could analyze CSR messages shared by women's PTSOs to understand what types of messages connect with fans of professional women's sports. Also, while Twitter is the platform that generally includes the most CSR messaging by organizations (Chalmeta \& Cortado, 2016), other platforms could be used for analysis including Facebook and Instagram.

As the leagues chosen for this study were the most popular leagues in the United States (Pasternak, 2020), future research could look internationally and consider CSR messaging by popular leagues in other countries. For example, scholars could analyze CSR messaging from teams within the English Premier League or Bundesliga.

Considering that CSR is a concept that applies to all organizations, future scholars could analyze CSR messages across sectors to better understand the best CSR messaging for sectorspecific publics. Specifically, CSR messaging in other sectors that have substantial influence in their countries (e.g., large entertainment organizations in the United States) could also be analyzed. 


\section{CHAPTER IV: CONCLUSION}

This study investigated professional team sport organizations' CSR messaging on Twitter and how fans engaged with topics and type of CSR messaging through replies on the platform. As referenced earlier, research in PTSO CSR is gaining traction, yet there is lacking foundational scholarship about how different types of CSR content shared on social media is received by fans. The present study attempted to address this gap in research; however, future research on the topics covered in this study is recommended to better understand PTSO CSR through a public relations lens.

CSR communication is a critical component of organizational success and longevity. Moreover, since professional sport is a sector dependent on fans for its success, understanding fan response to CSR communication is crucial. The results of this study indicated that PTSOs in the NFL, MLB, NBA, and NHL tend to share messages on their community pages of their websites about Health, Education, and Finance initiatives. Moreover, PTSOs tend to share messages about Business Development, Employee/Workplace Engagement, and Public Policy the least. On Twitter, PTSOs tend to share messages about Public Policy, Finance, and Diversity initiatives the most and messages about Safety, Employee/Workplace Engagement, and Business Development initiatives the least.

The results of this study indicated that reply valence to CSR messages was largely neutral, followed by positive and then negative. CSR messages about Finance, Diversity, and Health initiatives that were shared on Twitter received the most positive replies. There were significantly more CSR messages sharing not community-specific initiatives as opposed to community-specific initiatives. Finally, there was no significant difference of reply valence in replies to community-specific and not-community specific CSR messages. 
As social media, such as Twitter, are clear and effective avenues to communicate CSR with publics (Watkins, 2017), organizations must understand how to utilize their platforms to increase favorable public perception and fan purchase intention. When fans are involved in the online communication of CSR, organizations experience positive CSR outcomes (Kent \& Taylor, 2016). The results of the present study reinforce previous literature that fans have opinions about CSR and an understanding of which CSR topics are received most positively allows organizations to be strategic in sharing messages that align with the interests of their target publics (Abitol \& Lee, 2017).

While more research is needed to better understand CSR messaging in the professional sport sector, PTSOs can affect change in their communities through their CSR initiatives, and sharing these initiatives with fans online can have positive impacts on PTSO reputation and financial success. CSR is a strategy that benefits organizations and stakeholders, and better understanding CSR in this context is vital to ensuring this sector can strategically contribute to the public interest. 


\section{REFERENCES}

Ajayi, O. A. \& Mmutle, T. (2020). Corporate reputation through strategic communication of corporate social responsibility. Corporate Communications: An International Journal, $25,1-15$.

Abitol, A. \& Lee, S. Y. (2017). Messages on CSR-dedicated Facebook pages: What works and what doesn't. Public Relations Review, 43, 796-808.

Abuín-Penas, J., Babiak, K., \& Martínez-Patiño, M.J. (2020). Athlete’s philanthropy and social responsibility communication on social media during COVID-19. Journal of Human Sport and Exercise, 2020.

Andrassy, E. J. \& Bruening, J. E. (2011) From rhetoric to reality: NCAA division I athletic department mission statements and student-athlete community service efforts. Journal of Issues in Intercollegiate Athletics, 4, 271-288.

Andrews, M. (2020, July 21). NBA unveils Black Lives Matter on Orlando court. ESPN. https://www.espn.com/nba/story/_id/29510169/nba-unveils-black-lives-matter-orlandocourt

Ashforth, B. E. \& Mael, F. (1989). Social identity theory and the organization. The Academy of Management Review, 14(1), 21-39.

Associated Press. (2020, July 22). MLB to allow Black Lives Matter, social justice jersey patches. ESPN. https://www.espn.com/mlb/story/_/id/29519284/mlb-allow-black-livesmatter-social-justice-jersey-patches

Babiak, K. (2010). The role and relevance of corporate social responsibility in sport: A view from the top. Journal of Management and Organization, 16(4), 528-549. 
Babiak, K., \& Kihl, L. A. (2018). A case study of stakeholder dialogue in professional sport: An example of CSR engagement. Business \& Society Review, 123(1), 119-149.

Babiak, K., Mills, B., Tainsky, S., \& Juravich, M. (2012). An investigation into professional athlete philanthropy: Why charity is part of the game. Journal of Sport Management, 26(2), 159-176.

Babiak, K., \& Trendafilova, S. (2011). CSR and environmental responsibility: Motives and pressures to adopt green management practices. Corporate Social Responsibility \& Environmental Management, 18(1), 11-24.

Barone, M. J., Mayazaki, A. D., \& Taylor, K. A. (2000). The influence of cause-related marketing on consumer choice: Does one good turn deserve another? Journal of the Academy of Marketing and Science, 28(2), 248-262.

Becker-Olsen, K. L., Cudmore, B. A., \& Hill, R. P. (2006). The impact of perceived corporate social responsibility on consumer behavior. Journal of Business Research, 59, 46-53.

Bednarska-Wnuk, I. (2015). Social responsibility of organizations and temporary workers. Manifestations and dilemmas. La responsabilitat social de les organitzacions i els treballadors temporals. Manifestacions i dilemes. Tripodos, 37, 63-72.

Bhattacharya, C. B. \& Sen, S. (2004). Doing better at doing good: When, why, and how consumers respond to corporate social initiatives. California Management Review, 47(1), $9-24$.

Boen, F., Vanbeselaere, N., \& Feys, J. (2002). Behavioral consequences of fluctuating group success: An internet study of soccer-team fans. The Journal of Social Psychology, 142, $769-781$. 
Bortree, D. S. (2014). The state of CSR communication research: A summary and future direction. Public Relations Journal, 8, 1-8.

Branscombe, N. R. \& Wann, D. L. (1991) The positive social and self concept consequences of sports team identification. Journal of Sport and Social Issues, 15(2), 115-127.

Brammer, S. J., \& Millington, A. I. (2005). Corporate reputation and philanthropy: An empirical analysis. Journal of Business Ethics, 61(1), 29-44.

Brodie, R. J., Ilic, A., Juric, B., \& Hollebeek, L. (2013). Consumer engagement in a virtual brand community: An exploratory analysis. Journal of Business Research, 66(1) 105-114.

Buscarini, C. \& Maura, R. (2016). Italian sport federations: Communicating CSR through social report. In J. N. Paramio-Salcines, K. Babiak, \& G. Walters (Eds.), Routledge handbook of sport and corporate social responsibility (pp. 272-282). New York: Routledge.

Capriotti, P. \& Moreno, M. (2007). Corporate citizenship and public relations: The importance and interactivity of social responsibility issues on corporate websites. Public Relations Review, 33, 84-91.

Carroll, A. B. (1979). A three-dimensional conceptual model of corporate performance. The Academy of Management Review, 4(4). 497-505.

Carroll, A. B. (1999). Corporate social responsibility: Evolution of a definitional construct. Business and Society, 38(3), 268-295.

Clement, J. (2020, August 21). Most popular social networks worldwide as of July 2020, ranked by number of active users. Statista. https://www.statista.com/statistics/272014/globalsocial-networks-ranked-by-number-of-users/

Coombs, T. W. \& Holladay, S. J. (2012). Managing corporate social responsibility: A communication approach. Wiley-Blackwell. 
Chalmeta, R. \& Cortado, F. (2016). Use of social networks as a CSR communication tool. Cogent Business and Management, 3, 1-18.

Du, S., Battacharya, C. B., \& Sen, S. (2010). Maximizing business returns to corporate social responsibility (CSR): The role of CSR communication. International Journal of Management Reviews, 12, 8-19.

Eberle, T., Berens, G., \& Li, T. (2013). The impact of interactive corporate social responsibility communication on corporate reputation. Journal of Business Ethics, 118, 731-746.

End, C. M., Dietz-Uhler, B., Harrick, E. A., \& Jacquemotte, L. (2002). Identifying with winners: A reexamination of sport fans' tendency to BIRG. Journal of Applied Social Psychology, 32, $1017-1030$.

Esrock, S. L., \& Leighty, S. B. (1998). Social responsibility and corporate web pages: Self-presentation or agenda-setting? Public Relations Review, 24(3), 305-319.

Etter, M. (2013). Reasons for low levels of interactivity (non-) interactive CSR communication in Twitter. Public Relations Review, 39, 606-608.

Fisher, R.J., \& Wakefield, K. (1998). Factors leading to group identification: A field study of winners and losers. Psychology \& Marketing, 15, 23-40.

Fombrun, C. \& Shanley, M. (1990). What's in a name? Reputation building and corporate strategy. Academy of Management Journal, 33(2), 233-258.

Gan, A. (2006). The impact of public scrutiny on corporate philanthropy. Journal of Business Ethics, 69, 217-236.

Godfrey, P.C. (2009). Corporate social responsibility in sport: An overview and key issues. Journal of Sport Management, 23, 698-716. 
Godfrey, P. C., \& Hatch, N. W. (2007). Researching corporate social responsibility: An agenda for the 21st century. Journal of Business Ethics, 70(1), 87-98.

Gough, C. (2021, March 1). North American sports market size 2009-2023. Statista. https://www.statista.com/statistics/214960/revenue-of-the-north-american-sports-market/

Groza, M. D., Pronschinske, M. R., \& Walker, M. (2011). Perceived organizational motives and consumer responses to proactive and reactive CSR. Journal or Business Ethics, 102, 639652.

Hayes, R.A., \& Carr, C.T. (2021). Snark happens: Effects of schadenfreude on brand attitudes. Journal of Current Issues in Research and Advertising, 41(2), 243-256.

He, H., \& Harris, L. (2020). The impact of Covid-19 pandemic on corporate social responsibility and marketing philosophy. Journal of Business Research, 116, 176-182

He, Li, \& Harris (2011). Social identity perspective on brand loyalty. Journal of Business Research, 65, 648-657.

Heere, B., \& James, J. D. (2007). Sports teams and their communities: Examining the influence of external group identities on team identity. Journal of Sport Management, 21(3), 319337.

Hirt, E. R., Zillmann, D., Erickson, G. A., \& Kennedy, C. (1992). Costs and benefits of allegiance: Changes in fans' self-ascribed competencies after team victory versus defeat. Journal of Personality and Social Psychology, 63, 724-738.

Hou, J., \& Reber, B. H. (2011). Dimensions of disclosures: Corporate social responsibility (CSR) reporting by media companies. Public Relations Review, 37, 166-168.

Inoue, Y. \& Havard, C. (2015). Sport and disaster relief: A content analysis. Disaster Prevention and Management, 24(3), 355-368. 
James, G. \& Trail, G. T. (2008). The relationship between team identification and sport consumption intentions. International Journal of Sport Management, 9, 427-440.

Jarvie, G. (2003). Communitarianism, sport and social capital: "Neighbourly insights into Scottish sport.” International Review for the Sociology of Sport, 38, 139-153.

Johnston, K. A. (2014). Public relations and engagement: Theoretical imperatives of a multidimensional concept. Journal of Public Relations Research, 26, 381-383.

Joyner, B. E. \& Payne, D. (2002). Evolution and implementation: A study of values, business ethics, and corporate social responsibility. Journal of Business Ethics, 41, 297-311.

Kang, M. (2014). Understanding public engagement: Conceptualizing and measuring its influence on supportive behavioral intentions. Journal of Public Relations Research, 39, $399-416$.

Kearney, M. W. (2019). Rtweet: Collecting and analyzing Twitter data. Journal of Open Source Software, 4(42). 1829.

Kemp, S. (2020, July 21). Digital 2020: July global statshot. Datareportal. https://datareportal.com/reports/digital-2020-july-global-statshot

Kent, M. L. \& Taylor, M. (2016). From homo economicus to homo dialogicus: Rethinking social media use in CSR communication. Public Relations Review, 42(1), 60-67.

Kesavan, R. \& Bernacchi, M. D. (2013). Word of mouse: CSR communication and the social media. International Management Review, 9(1), 59-67.

Krippendorff, K. (1980). Content analysis: An introduction to its methodology. Sage.

Lacey, R., Kennett-Hensel, P., \& Manolis, C. (2015). Is corporate social responsibility a motivator or hygiene factor? Insights into its bivalent nature. Journal of the Academy of Marketing Science, 43, 315-332. 
Lacey, R., \& Kennett-Hensel, P. (2016). How expectations and perceptions of corporate social responsibility impact NBA fan relationships. Sports Marketing Quarterly, 25(1), 21-33.

Latapí Agudelo, M.A., Jóhannsdóttir, L., \& Davídsdóttir, B. (2019). A literature review of the history and evolution of corporate social responsibility. International Journal of Corporate Social Responsibility, 4, 1-23.

Lunenberg, K., Gosselt, J. F., \& De Jong, M. D. T. (2016). Framing CSR fit: How corporate social responsibility activities are covered by news media. Public Relations Review, $42,943-951$.

Manheim, J. B., \& Pratt, C. B. (1986). Communicating corporate social responsibility. Public Relations Review, 12(2), 9.

Matsuoka, H., Chelladurai, P., \& Harada, M. (2003). Direct and interaction effects of team identification and satisfaction on intention to attend games. Sport Marketing Quarterly, 12(4), 244-253.

Melnick, M. J. (1993). Searching for sociability in the stands: A theory of sports spectating. Journal of Sport Management, 7, 44-60.

Men, L. R. \& Tsai, W. S. (2014). Perceptual, attitudinal, and behavioral outcomes of organization-public engagement on corporate social networking sites. Journal of Public Relations Research, 26, 417-435.

Misener, K., Morrison, K, Shier, M., \& Babiak, K. (2020). The influence of organizational social responsibility on involvement behavior in community sport membership associations. Nonprofit Management and Leadership, 30(4), 591-611.

Norris, J. I., Wann, D. L., \& Zapalac, R. K. (2014). Sport fan maximizing: Following the best team or being the best fan? Journal of Consumer Marketing, 32(3), 157-166. 
Okazaki, S., Plangger, K., West, D., \& Menendez, H. (2020). Exploring digital corporate social responsibility communications on Twitter. Journal of Business Research, 117, 675-682.

Pasternak, M. (2020, March 9). What are the 5 most popular sports in the USA? Statscore. https://blog.statscore.com/what-are-the-5-most-popular-sports-in-the-usa/

Pew Research Center (2019). Social media fact sheet [Data file]. Retrieved from https://www.pewresearch.org/internet/fact-sheet/social-media/

Pfefferbaum, B. \& North, C. S. (2020). Mental health and the Covid-19 pandemic. New England Journal of Medicine, 383, 510-512.

Porter, M. E., \& Kramer, M. R. (2006). Strategy and society: The link between competitive advantage and corporate social responsibility. Harvard Business Review, 84(12), 78.

Riffe, D., Lacy, S., \& Fico, F. (2014). Analyzing media messages: Using quantitative content analysis in research. Routledge.

Sagawa, S. \& Segal, E. (2000). Common interest common good: Creating value through business and social sector partnerships. California Management Review 42(2), 105-122.

Sen, S., \& Bhattacharya, C. B. (2001). Does doing good always lead to doing better? Consumer reactions to corporate social responsibility. Journal of Marketing Research, $38(2), 225-243$.

Shaw, B, \& Post, F. R. (1993). A moral basis for corporate philanthropy. Journal of Business Ethics, 12, 745-751.

Sheth, H., \& Babiak, K. (2010). Beyond the game: perceptions and practices of corporate social responsibility in the professional sport industry. Journal of Business Ethics, 91, 433-450. 
Shim, K., \& Yang, S.U. (2016). The effect of bad reputation: The occurrence of crisis, corporate social responsibility, and perceptions of hypocrisy and attitudes toward a company. Public Relations Review, 42, 68-78.

Smith, A. C. T. \& Westerbeek, H. M. (2007). Sport as a vehicle for deploying corporate social responsibility. The Journal of Corporate Citizenship 25, 43-54.

Sutton, W. A., McDonald, M. A., Milne, G. R., \& Cimperman, J. (2012) Creating and fostering fan identification in professional sports. In N. L. Lough \& W. A. Sutton (Eds.), Handbook of sports marketing research, (p. 203-213). Morgantown, WV: Fitness Information Technology.

Tajfel, H., \& Turner, J. C. (1979). An integrative theory of intergroup conflict. The Social Psychology of Intergroup Conflict, 33, 47.

Uzunoğlu, E., Türkel, S., \& Akyar, B.Y. (2017). Engaging consumers through corporate social responsibility messages on social media: An experimental study. Public Relations Review, 43(5), 989-997.

Walzel, S., Robertson, J., \& Anagnostopoulos, C. (2018). Corporate social responsibility in professional team sports organizations: An integrative review. Human Kinetics Journal, 32(6), 511-530.

Wang, S., \& Gao, Y. (2016). What do we know about corporate social responsibility research? A content analysis. Irish Journal of Management, 35(1), 1-16.

Wann, D. L., Waddill, P. J., Polk, J., \& Weaver, S. (2011). The team identification-social psychological health model: Sport fans gaining connections to others via sport team identification. Group Dynamics: Theory, Research, and Practice, 15(1), 75-89. 
Wu, W. Y. and Tsai, C. H. (2007). The empirical study of CRM: Consumer-company identification and purchase intention in the direct selling industry. International Journal of Commerce and Management, 17(3), 194-210.

Wulfson, M. (2001). The ethics of corporate social responsibility and philanthropic ventures. Journal of Business Ethics 29(1/2), 135-145.

Yang, J., Basile, K., \& Letourneau, O. (2018). The impact of social media platform selection on effectively communicating about corporate social responsibility. Journal of Marketing Communication, 26, 65-87. 


\section{APPENDIX: CODEBOOK}

CSR Topic

1.Education

2.Health

3.Research and

Development

4.Business Development

6.Environment/Energy

7.Finance
Discusses learning, education, teaching for either children or adults

Concerns with overall health. This can include focusing on exercise, fitness, or overall wellness

Covers the creation of (new) technology, use of technology, or discussion of technology itself

Mentions starting a business, maintaining/sustaining a business, or improving businesses. Can include mentions of job growth or highlighting executive members

Mentions safety issues, protocols, or implementation

Discusses topics such as the environment, wildlife preservation, conservation of any kind, and energy of any kind

Mentions programs specifically having to do with finance or accounting. This can include highlighting financial programs put on by the community
Example

We are so proud to partner with a.BCBSWNY to welcome teachers and students back to school safely! \#LetsGoBuffalo

Game on Cancer helps vulnerable Cancer patients tackle the extra financial costs of cancer treatment. We fund patient expenses like transportation, groceries, housing costs, prescriptions and medical supplies. Join us here: https://t.co/flrZ4yQNoR

In this week's Transformation Thursday, Wilson Electric Service Corporation CEO Wes McClure walks us through how they're approaching rewiring the arena. More on \#Project21.

This week we get an assist from Cam Johnson as we walk through the latest progress in the revamped Pavilion and Suns locker room.

Schwartz confirms Durant will have to go through concussion testing again to get back on the field. "it's not something you can tough out."

We've partnered with @DTE_Energy for National Energy Efficiency Day to recognize the benefits of energy efficiency and provide ways for you to manage your own energy use and save!

The Detroit Lions Virtual Locker Room Sale is happening now! Shop hundreds of items like apparel and autographed memorabilia at bargain prices. Proceeds benefit Detroit Lions Charities. 
8.Religion

9.Public Policy

10. Employee/Workplace

Engagement

11.Diversity
Explicitly mentions a specific religion or holiday

Discusses overall government or law making initiatives

Describes benefits to employee/ workplace welfare or the workplace

Discusses minority or disenfranchised groups. This includes the LGBTQIA+ community and certain races
Happy Easter!

With less than 24 hours until

Election Day, make sure you have a plan! Check your polling location and sample ballot today!

\#NFLVotes

We're proud of the work you're doing off the court @ cheick_diallo13 Congrats on starting your own foundation and we can't wait to see the impact you'll create!

Purchase a Salute to Service Fan Cutout in honor or in memory of a soldier. Proceeds from Salute to Service cutouts benefit @TAPSorg 
Action-Oriented (1) or

not Action-Oriented (2)
Hands-on/In-person engagements

Not hands on engagements
Don't miss your chance to participate in a virtual autograph sessionwith@Matt_Prater_5!

Proceeds benefit @GameOnCancerDET

As a part of the greater \#NFLVotes initiative, the Lions will be providing essential voter information leading up to Election Day on November $3^{\text {rd }}$.
Community-Specific (1) or

Not Community-Specific (2)
Engagement in the team's community: any tweet unit that mentions the team's state, city, or county

Engagement not specific to the team's community: any tweet unit that does not mention the team's state, city, or county
Listen to@mattboyd48 and \#VOTE!

If you're in Michigan, polls close at 8:00 ET. If you haven't registered to vote, there's still time. Learn more at https://t.co/A1cVEp20F1
Low Engagement (1) or

High Commitment (2)
Short-term initiatives, do not require substantial resources to sustain the initiative

Long-term initiatives, need to be sustained by the organization and require resources to do so
We are hosting an online auction in conjunction with the $13^{\text {th }}$ Annual Sabres Foundation Golf Tournament

Let's keep the conversation going. Here is our commitment to working with our community to promote equality and justice for all. https://t.co/2Wd606dqAK
Positive Reply Valence (1)

Neutral Reply Valence (0)

Negative Reply Valence (-1)
I'll never give up on my Lions $<3$

aye can I get a follow back?

Does my vote count when I tell Ford to sell the team? Or to get rid of this horrendous coaching staff? 